\section{Physiological engineering of Pseudomonas aurantiaca antimicrobial activity: effects of sodium chloride treatment}

\author{
Linda Rozenfelde, ${ }^{1}$ \\ Galina Khroustalyova, ${ }^{1}$ Marina Mandryk, ${ }^{2}$ \\ Emily Kolomiets, ${ }^{2}$ Alexander Rapoport ${ }^{1}$ \\ 1 Laboratory of Cell Biology, Institute \\ of Microbiology and Biotechnology, \\ University of Latvia, Riga, Latvia; \\ ${ }^{2}$ Laboratory of Biological Control, \\ Institute of Microbiology, Belarus \\ Academy of Sciences, Minsk, Belarus
}

\begin{abstract}
The influence of sodium chloride $(\mathrm{NaCl})$ treatment on the antifungal activity of the bacterium Pseudomonas aurantiaca, a producer of biopesticide for vegetable plants, was investigated. It was shown that an increase in the $\mathrm{NaCl}$ concentration in incubation solutions from $1 \mathrm{M}$ to $3 \mathrm{M}$ led to a significant increase in the antifungal activity of this bacterium. Antifungal activity continued to increase with prolonged treatment of bacteria in fresh nutrient medium from $72 \mathrm{~h}$ to $96 \mathrm{~h}$. These findings could be very important for the further development of biotechnological processes directed not only to the production of new active biopesticides but also of other valuable resources.
\end{abstract}

\section{Introduction}

It is well known that the global population is expected to grow very significantly in the next decades. This means that an additional increase in agricultural production will be required. However, the availability of arable area is on the decline and most soils with high productivity potential are already under cultivation. This problem can only be solved by improvements in crop productivity with appropriate control of plant pests, diseases and weeds. ${ }^{1}$ World-wide losses of crop production due to different plant diseases are close to $13 \%$, and such a situation significantly reduces the production of food. About 11,000 diseases are induced by 120 genera of fungi, 30 types of viruses and 8 genera of bacteria. ${ }^{2}$ Currently, the control of plant diseases is achieved mainly by chemically synthesized pesticides. ${ }^{3}$ However, the use of chemical pesticides has a negative environmental impact due to the fact that these compounds may pass through the soil and subsoil and pollute surface waters and groundwater. ${ }^{4}$ They are also toxic to living organisms and can negatively affect human health. ${ }^{5-7}$ The only way to solve this problem is to use environmentally-friendly pesticides such as biopesticides. Biopesticides are represented by live organisms or natural products derived from these organisms that suppress crop diseases. They usually offer several advantages over traditional chemical pesticides. Biopesticides are safer for the environment and they can offer much more targeted activity. They are often effective in very small quantities and decompose more quickly than conventional chemical pesticides. ${ }^{3}$ At the moment, biopesticides take up a small share of the total pesticide market; however, over the past five years, the synthetic pesticide market has been declining and, at the same time, the biopesticide market has been growing. ${ }^{8}$ There is a definite need for further detailed research and improvements to biopesticides to make them more efficient agricultural technologies.

Pseudomonas species are some of the most important bacteria inhabiting the rhizosphere of diverse crop plants. Soil-borne bacteria of the Pseudomonas genus can exert antagonistic properties on plant pathogens. They might act as efficient biological control agents able to prevent plant diseases and serve as an efficient alternative to chemical pesticides in agriculture. ${ }^{9}$ This is linked to their ability to produce different types of antibacterial and antifungal compounds. One of the goals of further research on microbial biopesticides is to promote the maximum activity of their active ingredients. ${ }^{10}$ This can be achieved by searching for new, more active strains or by improving the action of previously selected, existing and efficient strains. Gene engineering and metabolic engineering methods can be used to make such improvements. In spite of the great potential of these modern approaches, they also have some disadvantages. The aim of our study was to improve the activity of efficient strains of biopesticide-producing Pseudomonas aurantiaca by the use of a physiological approach. In the current study, we investigated the possible impact of treatment with sodium chloride $(\mathrm{NaCl})$ on the synthesis of antimicrobial metabolites by Pseudomonas aurantiaca.

\section{Materials and Methods}

The bacterium Pseudomonas aurantiaca S-1 used in this study was received from the microbial collection of the Institute of Microbiology at the National Academy of Sciences of Belarus. The bacterial culture was grown in $750 \mathrm{~mL}$ flasks with $100 \mathrm{~mL}$ of Mejnell's nutrient medium which contained (in $\mathrm{g} \mathrm{l}^{-1}$ ): $\mathrm{K}_{2} \mathrm{HPO}_{4} \cdot 3 \mathrm{H}_{2} \mathrm{O} \quad 7.0 ; \mathrm{KH}_{2} \mathrm{PO}_{4} 3.0$;
Correspondence: Linda Rozenfelde, Laboratory of Cell Biology, Institute of Microbiology and Biotechnology, University of Latvia, Kronvald Blvd. 4, LV-1586 Riga, Latvia.

Tel. +371.67034891 - Fax: +371.67034885

E-mail: lindyr@inbox.lv

Key words: biopesticides, biological control, activation of metabolism, dehydration, anhydrobiosis.

Acknowledgements: this work was supported by grants from the science and technology cooperation program of the Ministry of Education and Science of the Republic of Latvia and the State Science and Technology Committee of the Republic of Belarus.

Contributions: AR and EK supervised the project; LR, GK and MM designed and performed experiments; LR and AR wrote the paper.

Conflict of interests: the authors report no conflict of interests.

Received for publication: 19 October 2011.

Revision received: 25 May 2012.

Accepted for publication: 11 June 2012.

This work is licensed under a Creative Commons Attribution NonCommercial 3.0 License (CC BYNC 3.0).

CC Copyright L. Rozenfelde et al., 2012

Licensee PAGEPress, Italy

Microbiology Research 2012; 3:e26

doi:10.4081/mr.2012.e26

$\mathrm{MgSO}_{4} \cdot 7 \mathrm{H}_{2} \mathrm{O} 0.1 ; \mathrm{NH}_{4} \mathrm{NO}_{3} 1.0 ; \mathrm{C}_{6} \mathrm{H}_{5} \mathrm{O}_{7} \mathrm{Na}_{3} \cdot 3 \mathrm{H}_{2} \mathrm{O}$ 0.5 ; molasses 30 . The $\mathrm{pH}$ value of the nutrient medium was adjusted to $\mathrm{pH}$ 7.0. Bacterial cultures were cultivated using a rotary shaker at a rotation speed of $180 \mathrm{rpm}$ at $30^{\circ} \mathrm{C}$ for $24 \mathrm{~h}$. To perform the $\mathrm{NaCl}$ treatment, harvested bacterial biomass was then incubated in $1 \mathrm{M}, 2 \mathrm{M}, 3$ $\mathrm{M}$ and $4 \mathrm{M} \mathrm{NaCl}$ solutions for $3 \mathrm{~h}$ at $30^{\circ} \mathrm{C}$. Next, $0.5 \mathrm{~mL}$ of microbial culture subjected to the treatment or not subjected to the treatment (control) were taken from each solution for inoculation into fresh Mejnell's medium. After re-incubation of $P$ s. aurantiaca for $72 \mathrm{~h}$ or $96 \mathrm{~h}$, the antifungal metabolite synthesis was measured. An evaluation of the antifungal activity of cell-free supernatants of $P$ s. aurantiaca culture medium was carried out using spectrophotometry. The absorption spectrum was measured between $300 \mathrm{~nm}$ and $700 \mathrm{~nm}$ using an Ultrospec 2100 Pro spectrophotometer with a 1 $\mathrm{cm}$ disposable sample cell. Pure medium was used as a reference. The size of the peak in the area of $400 \mathrm{~nm}$ was used for the determination of antifungal activity. All experiments were performed in five replicates, and representative results are presented. To check the validity of this method of determining antimicrobial activity, in some experiments, antifungal activ- 
ity was also determined using the traditional agar well diffusion method. ${ }^{11}$ In this assay, the fungus Fusarium oxysporum NR 259 was used as the test culture, obtained from the Microbial Strain Collection of Latvia. This culture is known to be a vegetable and fruit pathogen. The fungus $F$. oxysporum was cultivated on solid PDA (potato dextrose agar) medium for $48 \mathrm{~h}$. Circular wells $(6 \mathrm{~mm})$ were cut in the agar culture medium and filled with $70 \mu \mathrm{L}$ of liquid cultivation medium obtained from $P$ s. aurantiaca culture grown in Meinell's medium for $72 \mathrm{~h}$ or $96 \mathrm{~h}$. Antifungal activity was measured as the inhibition of fungal growth from the edge of wells to the end of the fungal inhibition zone (in $\mathrm{cm}$ ).

\section{Results and Discussion}

Our previous studies on anhydrobiosis (a temporary reversible delay of metabolism) of microorganisms achieved by significant dehydration of cells showed that cell transfer into this state is connected with a number of intracellular changes at the molecular, structural and cellular levels. It was revealed that some compounds were synthesized in the cells; this does not usually happen in their normal state. Unusually, the activation of some metabolic processes was also observed. Most interestingly, these effects were not only linked with the increased synthesis of protective compounds, but also with the synthesis of some other compounds, as well as with the activation of growth and of fermentation processes. ${ }^{12-16}$ It was shown that the physiological state of cells can be changed or improved during incubation in solutions with increased osmotic pressure, thus creating conditions that lead to the dehydration of microorganisms. ${ }^{16-19}$ In our current work, we attempted to reveal if similar stress treatment can also efficiently increase the physiological antimicrobial activity of the bacterium Ps. aurantiaca, a producer of biopesticides. As the chemical compound used to increase the osmotic pressure, we chose $\mathrm{NaCl}$ because it is safe and is one of the cheapest substances available. Both these characteristics seemed, to us, to be very important in the event that $\mathrm{NaCl}$ treatment demonstrated positive effects and could be recommended for biotechnological application. In our experiments, we used different concentrations of this salt, from $1 \mathrm{M}$ to $4 \mathrm{M}$. It is necessary to mention here that in another series of experiments that were performed simultaneously with this study, we investigated possible changes in the antimicrobial activity of $P S$. aurantiaca as a result of another stress treatment, i.e. heat shock. In these experiments, for the determination of antimicrobial activities, we used the conventional but labour- and timeconsuming agar well diffusion method and spectral analysis of cell-free supernatants of Ps. aurantiaca culture medium. The latter was applied on the basis of earlier results which showed that Ps. aurantiaca cell-free culture media supernatants present a spectral peak at $390-420 \mathrm{~nm}$ associated with the antifungal activity of this bacterium. ${ }^{20}$ Our results from studies on the effects of heat shock showed that there was very good correlation between these data. On the basis of these results, it was decided to use the rather convenient spectral method for the evaluation of antifungal activity of our strain of PS. aurantiaca (G Khroustalyova, N Zharova, L Rozenfelde, M Mandryk, E Kolomiets, A Rapoport, manuscript in preparation). Therefore, this very convenient methodological approach was used in this study on the influence of $\mathrm{NaCl}$ upon the antifungal activity of $P$ s. aurantiaca. The results of this work are shown in Figures 1 and 2. Figure 1 represents the typical spectral analysis of cell-free supernatants of Ps. aurantiaca culture medium. To facilitate further discussion, Figure 2 shows the results of a typical experiment with changes in the height of the main absorbance peak at $390-400 \mathrm{~nm}$. This was previously shown to correspond to the antifungal activity of this strain. ${ }^{20}$ It can be seen from both figures that the use of inoculum previously treated with various concentrations of $\mathrm{NaCl}$ (1-4 M) led to an increase in the antifungal activity of the bacterial culture grown for $72 \mathrm{~h}$ or $96 \mathrm{~h}$. It is also clear that an increase in the $\mathrm{NaCl}$ concentration from $1 \mathrm{M}$ to $3 \mathrm{M}$ definitely increased the effect of the treatment. The same effect was also revealed with an extension of the duration of bacterial growth (from $72 \mathrm{~h}$ to 96 h). The highest level of antifungal activity was found after $96 \mathrm{~h}$ of growth in the inoculum previously subjected to incubation in a $3 \mathrm{M}$ solution of $\mathrm{NaCl}$; this increased by up to 3.25 times compared with the activity of the control culture. To be sure of the validity of this spectral method used for the evaluation of antifungal activity, in some experiments performed simultaneously with this method, we also used

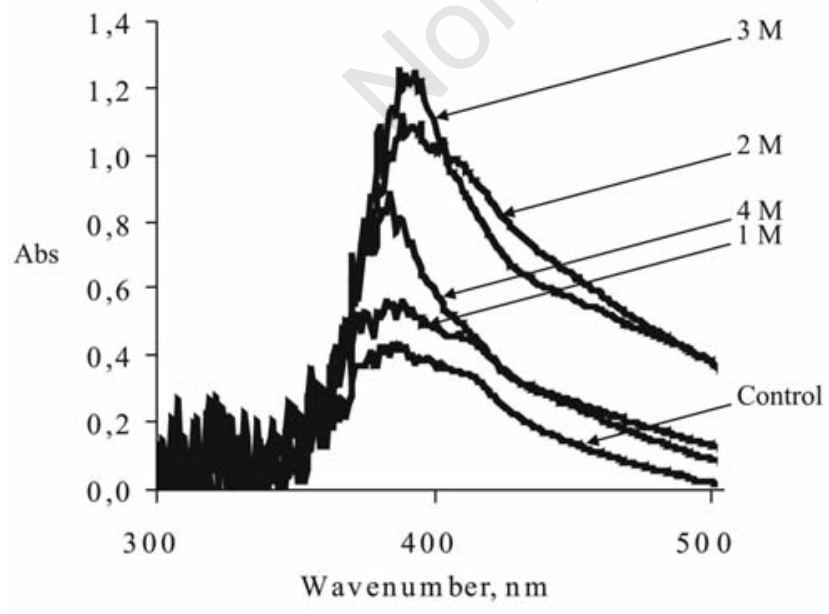

Figure 1. Typical spectra of cell-free cultural medium supernatants of Ps. aurantiaca, grown in fresh nutrient medium after incubation in solutions with different concentrations of sodium chloride (1 M - $4 \mathrm{M})$. The control sample was not subjected to sodium chloride treatment.

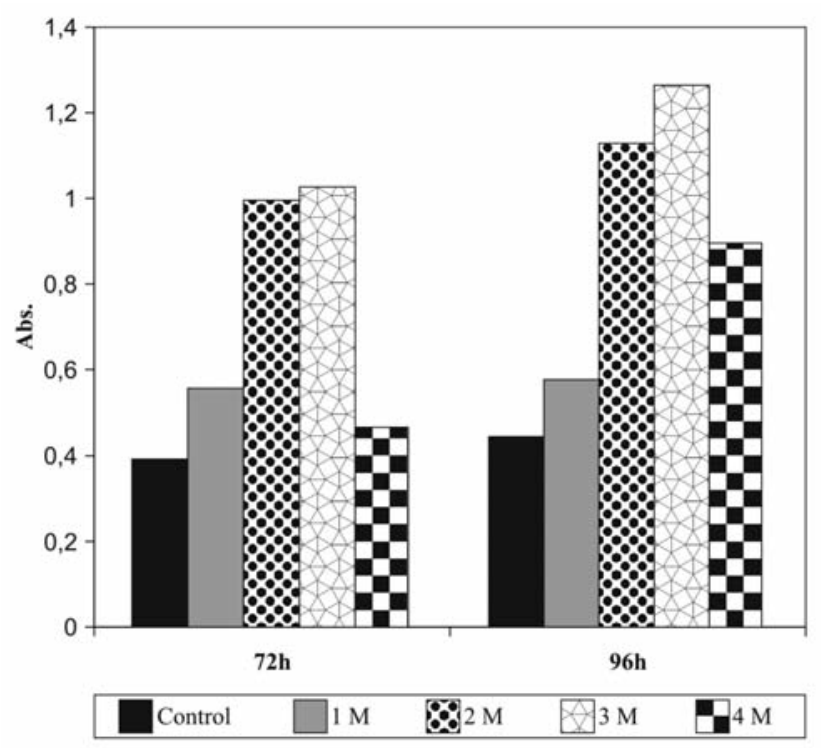

Figure 2. Absorbance at $400 \mathrm{~nm}$ of cell-free cultural medium supernatants of $P$ s. aurantiaca, grown in fresh nutrient medium for 72 and $96 \mathrm{~h}$ after sodium chloride treatments $(1 \mathrm{M}-4 \mathrm{M})$ and of the control sample which was not subjected to sodium chloride treatment. 
the traditional agar well diffusion method. ${ }^{11}$ Typical results of these experiments are shown in Figure 3. A comparison of the results obtained by these two methods is summarized in Table 1. It can be seen that there is a good correlation between the results obtained by each of these two methods. Of course, the figures also show that there are some differences and it seems that the use of the spectral method sometimes provides slightly more positive results than the traditional agar well diffusion method. At the same time, the tendency for an increase in antifungal activity after the treatment of bacteria with $\mathrm{NaCl}$ solutions as well as the dependence of such an increase on the concentration of the solution can clearly be seen with the use of any of the applied meth- ods. So, in summary, our results reveal very significant activation of the metabolism of a bacterial culture of $P s$. aurantiaca that can then be used as an inoculum for the production of antifungal compounds. This activation of metabolism was linked with an increase in the concentration of $\mathrm{NaCl}$ used for the incubation of bacteria and, correspondingly, with an increase in the osmotic pressure of the solution. It is clear that these conditions induce preliminary dehydration in microbial cells that, of course, does not lead to a delay in metabolism (anhydrobiosis) but rather a change in intracellular metabolism in the direction of activation of a number of intracellular protective reactions for the maintenance of cell viability.

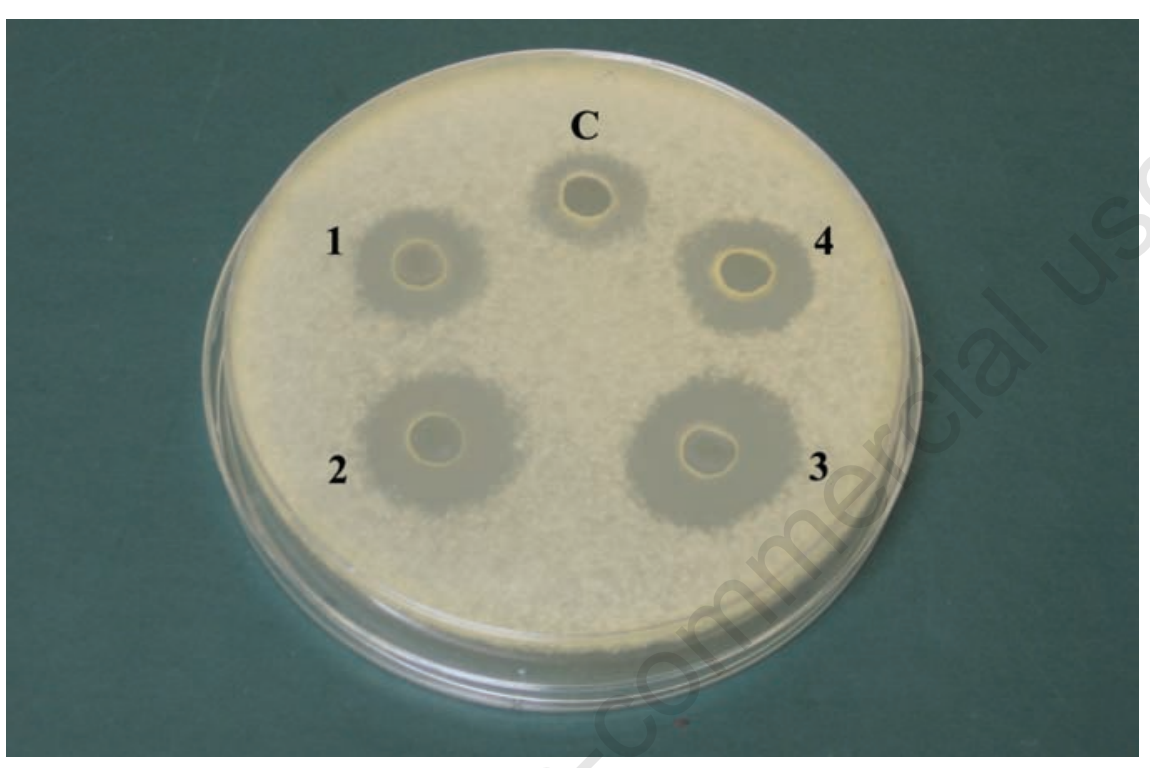

Figure 3. Antifungal activity of cell-free cultural medium supernatants of Ps. aurantiaca, grown in fresh nutrient medium for $96 \mathrm{~h}$ after sodium chloride $(\mathrm{NaCl})$ treatments $(1 \mathrm{M}$ $-4 \mathrm{M})$ and of the control sample against the phytopathogenic fungus $F$. oxysporum. 1 - 1 M, 2 - 2 M, 3 - 3 M, 4 - 4 M, C - reference sample (control). Results were obtained with the use of the agar well diffusion method.

Table 1. Comparison of the results on the antifungal activity of cell-free cultural medium supernatant of Ps. aurantiaca, grown for $96 \mathrm{~h}$, obtained by the spectral method and agar well diffusion method.

\begin{tabular}{|c|c|c|c|c|}
\hline \multirow[t]{2}{*}{ Sample } & \multicolumn{2}{|c|}{ Spectral method } & \multicolumn{2}{|c|}{ Agar well diffusion method } \\
\hline & $\begin{array}{l}\text { Absorbance } \\
\text { at } 400 \mathrm{~nm}\end{array}$ & $\begin{array}{l}\text { Absorbance } \\
\text { increase } \\
\text { to control, } \\
\text { times }\end{array}$ & $\begin{array}{l}\text { Fungus growth } \\
\text { inhibition } \\
\text { zone } \\
\text { size, } \mathrm{cm}\end{array}$ & $\begin{array}{l}\text { Inhibition } \\
\text { zone size } \\
\text { increase } \\
\text { to control, times }\end{array}$ \\
\hline
\end{tabular}

\begin{tabular}{lcccc}
\hline Control & 0.4 & - & 0.30 & - \\
$1 \mathrm{M} \mathrm{NaCl}$ & 0.5 & 1.25 & 0.43 & 1.43 \\
\hline $2 \mathrm{M} \mathrm{NaCl}$ & 1.1 & 2.75 & 0.65 & 2.16 \\
$3 \mathrm{M} \mathrm{NaCl}$ & 1.3 & 3.25 & 0.82 & 2.73 \\
\hline $4 \mathrm{M} \mathrm{NaCl}$ & 0.8 & 2 & 0.61 & 2 \\
\hline
\end{tabular}

$\mathrm{NaCl}$, sodium chloride.

\section{Conclusions}

We propose that it would be very interesting to study the reasons why, under these conditions, protective reactions take place as well as the activation of metabolic pathways that are not directly connected to the maintenance of cell viability. As previously mentioned, we have also shown the activation of other metabolic routes which are also not directly connected with cell viability. ${ }^{13-14}$ Nevertheless, the present results show that such stress treatment to cells of Ps. aurantiaca leads to the activation of cryptic metabolic pathways. In 1994, Jens Nielsen proposed a new term: physiological engineering. ${ }^{21}$ We propose that the effects of the stress treatments shown in this study can also be considered as an approach to physiological engineering, and that this method could be very efficient not only for the production of biopesticides by $P$ s. aurantiaca, but in various other biotechnological processes as well.

\section{References}

1. Oerke EC, Dehne HW. Safeguarding production - losses in major crops and the role of crop protection. Crop Prot 2004;23:27585 .

2. Agrios GN. Plant pathology. $4^{\text {th }}$ ed. New York: Academic Press; 1997.

3. Thakore Y. The biopesticide market for global agricultural use. Industrial Biotechnology 2006;2:194-208.

4. Ormad MP, Miguel N, Claver A, et al. Pesticides removal in the process of drinking water production. Chemosphere 2008;71:97-106.

5. Bassil KL, Vakil C, Sanborn M, et al. Cancer health effects of pesticides: systematic review. Can Fam Physician 2007;53:1704-11.

6. Hancockl DB, Martin ER, Mayhew GM, et al. Pesticide exposure and risk of Parkinson's disease: A family-based casecontrol study. BMC Neurol 2008;8:6.

7. Hernandez AF, Parron T, Alarcon R. Pesticides and asthma. Curr Opin Allergy Clin Immunol 2011;11:90-6.

8. Bailey KL, Boyetchko SM, Längle T. Social and economic drivers shaping the future of biological control: a Canadian perspective on the factors affecting the development and use of microbial biopesticides. Biolog Control 2010;52:221-9.

9. Costa R, Gomes CMN, Peixoto SR, et al. Diversity and antagonistic potential of Pseudomonas spp. associated to the rhizosphere of maize grown in a subtropical organic farm. Soil Biol Biochem 2006; 


\section{8:2434-47.}

10. Nakkeeran S, Dilantha Fernando WG, Siddiqui ZA. Plant growth promoting Rhizobacteria formulations and its scope in commercialization for the management of pests and diseases. In: Siddiqui ZA. PGPR: biocontrol and biofertilization. Dordrecht: Springer; 2006. pp. 257-296.

11. Barefoot SF, Klaenhammer TR. Detection and activity of Lactacin B, a bacteriocin produced by Lactobacillus acidophilus. Appl Environ Microbiol 1983;45:1808-15.

12. Beker MJ, Rapoport AI. Conservation of yeasts by dehydration. Adv Biochem Eng Biotechnol 1987;35:127-71.

13. Rapoport AI, Dreimane MA, Beker ME. Influence of the dehydration process on
Endomycopsis fibuligera yeasts. Microbiology 1986;55:542-5.

14. Rapoport AI, Khroustalyova GM, Kuklina EN. Anhydrobiosis in yeast: activation effect. Braz J Med Biol Res 1997;30:9-13.

15. Bekers M, Ventina E, Karsakevich A, et al. Attachment of yeast to the modified stainless steel wire spheres, growth of cells and ethanol production. Process Biochemistry 2000;35:523-30.

16. Bekers M, Vigants A, Laukevics J, et al. The effect of osmo-induced stress on product formation by Zymomonas mobilis on sucrose. Int J Food Microbiol 2000;55:14750.

17. Rapoport AI, Beker ME. Effect of sucrose and lactose on resistance of the yeast
Saccharomyces cerevisiae to dehydration. Microbiology 1983;52:556-9.

18. Rapoport AI, Puzyrevskaya OM, Saubenova MG. Polyols and resistance of yeasts to dehydration. Microbiology 1988;57:269-71.

19. Rapoport AI, Khroustalyova GM, Crowe LM, Crowe JH. Anhydrobiosis in yeast: stabilization by exogenous lactose. Microbiology 2009;78:624-9.

20. Mandryk MN, Kolomiets EI, Dey ES. Characterization of antimicrobial compounds produced by Pseudomonas aurantiaca S-1. Polish J Microbiol 2007;56:24550.

21. Nielsen J. Physiological engineering aspects of Penicillium chrysogenum. 